\title{
Discricionariedade: Juízo de Empate
}

\author{
Discretionary: Judgment of a Tie \\ Fábio Corrêa Souza de Oliveira ${ }^{1}$ \\ ${ }^{1}$ Universidade Federal do Rio de Janeiro (UFRJ), Rio de Janeiro - RJ, Brasil.
}

\begin{abstract}
Resumo: Este estudo está voltado para um dos temas mais problemáticos não apenas do Direito Administrativo, mas do Direito em outros âmbitos, que é a conceituação e a operacionalidade do juízo discricionário. Pretende-se explicitar como a discricionariedade, em que pese a centralidade da sua importância, é uma noção mal compreendida e que apresenta diferentes e divergentes concepções. O exame detido do objeto em questão revela confusões e contradições teóricas, o que, portanto, demanda um esforço para o bem do esclarecimento e da exatidão terminológica e de definição. Este artigo toma como campo investigativo, sobretudo, a doutrina administrativa brasileira.
\end{abstract}

Palavras-chave: Discricionariedade. Direito Administrativo. Vinculação.

\begin{abstract}
This study is aimed at one of the most problematic issues not only of Administrative Law, but of Law as a whole, which is the conceptualization and operability of the discretionary judgment. It seeks to explain how discretion, in spite of the centrality of its importance, is a misunderstood notion and that presents different and divergent conceptions. The examination of the object in question reveals theoretical confusions and contradictions, which therefore requires an effort for the sake of clarification and terminological accuracy and definition. This article takes as investigative field, above all, the Brazilian administrative doctrine.
\end{abstract}

Keywords: Discretionary. Administrative Law. Linking.

\section{Notas Iniciais}

Poucos temas despertam tanta atenção e tamanho debate e ainda assim seguem em divergências e em mal-entendidos quanto a questão da discricionariedade. É realmente uma questão central. Livros e artigos escritos a respeito, monografias, dissertações e teses, palestras e mais palestras. Mesmo com toda a produção referente e paradoxalmente e exa-

Recebido em: 08/11/2017

Revisado em: 1\%03/2018

Aprovado em: 15/04/2018

Direito autoral e licença de uso: Este artigo está licenciado sob uma Licença Creative Commons.Com essa licença você pode compartilhar, adaptar, para qualquer fim, desde que atribua a autoria da obra, forneça um link para a licença, e indicar se foram feitas alterações. 
tamente por ela, a problemática permanece, longe de um consenso mais largo e firme. O panorama não é exclusividade brasileira.

O que é juízo discricionário? A discricionariedade é o comum ou a raridade nas avaliações jurídicas? O Poder Judiciário pode examinar o juízo discricionário? Essas três perguntas sintetizam as polêmicas em torno do assunto: respostas diferentes e diametralmente opostas seguem sendo dadas. Com frequência, ao se indagar em uma turma de bacharelandos em Direito se o Judiciário está legitimado a sindicar o juízo discricionário, metade responde que sim e a outra metade responde que não. A jurisprudência, aliás, reflete a dissonância, inclusive a do Supremo Tribunal Federal, embora tenha havido certa confluência nos últimos anos.

Além da Teoria do Direito, as disciplinas que reúnem mais estudos aplicados concernentes à discricionariedade são o Direito Constitucional e o Direito Administrativo (CADEMARTORI; OLIVEIRA, 2016). Sem embargo, a questão do juízo discricionário é antes uma questão central da Filosofia do Direito, da Teoria do Direito (ENTERRÍA, 1997, p. 31) ${ }^{1}$. É objeto da Teoria da Decisão, envolvendo a Teoria da Norma. Tem sede na Hermenêutica. Empobrece a discussão tratar do juízo discricionário desconhecendo, por exemplo, a Filosofia da Linguagem.

Cadeiras como o Direito Administrativo ainda se ressentem da pouca incorporação da doutrina que tem lugar na Filosofia, na Hermenêutica, onde se operou(a) o giro linguístico, os movimentos de crítica/erosão do jusnaturalismo e do juspositivismo. Todavia, um conjunto de razões fez com que nos últimos anos se despertasse mais atenção à problemática da discricionariedade. Entre elas, vale citar: 1) a discussão acerca dos direitos fundamentais (embasamento, amplitude, eficácia, efetividade); 2) a discussão sobre o papel normativo da Constituição (força jurídica/ caráter vinculante das suas disposições, inclusive as programáticas); 3) a discussão a respeito da legitimidade da atuação do Estado em cada uma das suas três funções clássicas e, portanto, como o juízo discricionário se apresenta na legislação, na jurisdição e na administração; 4) neste último contexto, o fenômeno da judicialização e do ativismo judicial,

1 "La cuestión del control judicial del ejercicio de las potestades discrecionales de la Administración es un tema clásico de la teoria del Derecho". 
É neste cenário que autores vão se antagonizar em relação à questão das decisões discricionárias. No debate contemporâneo, um diálogo famoso e com muita repercussão é aquele travado entre Ronald Dworkin (1977) e Robert Alexy (1993)². Dworkin sustentando que os juízos discricionários, se é que existem - lembrando que Dworkin defende a tese da única resposta certa -, são muito raros em sistemas jurídicos complexos (recordando a imagem dworkiniana do romance em cadeia, fincado na tradição, na integridade, na coerência, uma concepção não convencionalista e nem jusnaturalista, bem como que a figura do juiz hércules é uma idealização, assim admitida pelo próprio autor, e oposta ao juiz solipsista, subjetivista), enquanto Alexy, expoente do que se convencionou denominar de teoria da argumentação, sustenta que os juízos discricionários são mais comuns do que se pode supor ou do que Dworkin gostaria, uma vez que compreende haver frequentemente múltiplas respostas possíveis a despeito do esforço metodológico (que ele mesmo empreende) a bem da racionalização.

Vale ainda ressaltar que a normatividade dos princípios afirmada por Dworkin, mas também por Alexy, importa, mais no primeiro do que no segundo, em uma cruzada contra a discricionariedade, que, pelo menos sob certo recorte, é bandeira de identidade do positivismo. Daí a conversação entre Dworkin e Herbert Hart. Ponto central nessa temática é, pois, a relação entre Direito e Moral, calhando lembrar que Alexy caracteriza a teoria dworkiniana como uma teoria forte da moral, concepção por ele rejeitada. Em Dworkin (1977, p. 28), não é correto concluir que há discricionariedade quando não existe uma regra para a hipótese, uma vez que princípio há. $\mathrm{E}$ a existência de princípio não leva, necessária ou normalmente, a mais de uma resposta certa. Segundo o autor estadunidense, princípios ensejam uma única resposta certa ${ }^{3}$.

A questão da discricionariedade, estudada nas três funções do Estado e com aspectos específicos em cada uma e mesmo para além delas, ganhou um grau de meditação que acompanha a sua problemática.

\footnotetext{
${ }^{2}$ Entre outras obras dos autores.

3 "In cases like these, principles play an essential part in arguments supporting judgments about particular legal rights and obligations."
} 
Daí ser uma questão que pode receber respostas diferentes se vista pelas lentes da denominada Teoria Material do Direito ou da Constituição ou da Teoria Processual, valendo sublinhar que Habermas (2003), expoente do procedimentalismo, se bateu contra a discricionariedade, como algo que se volta contra a democracia (o agir comunicativo), embora por meio de fundamentação diversa da de Dworkin (este um conteudista), uma vez que, na perspectiva habermasiana, a resposta certa tem a sua legitimidade advinda do cumprimento do processo dialógico (embora com a base substantiva dada pelas condições do discurso - situação ideal de fala) e, como tal, fonte do consenso deliberativo (HABERNAS, 2003).

Este artigo não se ocupa propriamente da base filosófica que é preliminar à formulação que a temática encontra no terreno do Direito Administrativo ou do Direito Constitucional. Ademais, muitos outros fatores influem na caracterização da discricionariedade. Um deles é o fato de a questão, nomeadamente em relação a certas matérias, se colocar perante o marco de uma Constituição Dirigente (OLIVEIRA, 2010). De um modo geral, é cabível afirmar que o espaço discricionário é menor diante de uma Constituição Dirigente do que de uma Constituição Negativa/Sintética/Formal. O que se faz aqui é evidenciar impasses/equívocos teóricos basilares, especialmente tendo por esteio o Direito Administrativo.

O objeto deste estudo é, pois, a compreensão do que é juízo discricionário, nomeadamente a partir das lentes do Direito Administrativo, embora em abordagem afinada à Teoria do Direito. A metodologia apropriada é a da revisão bibliográfica, perpassando a doutrina estrangeira, nomeadamente Ronald Dworkin, e a doutrina brasileira. Os objetivos gerais convergem em situar a problemática do juízo discricionário na Teoria do Direito, com ênfase na formulação administrativista. Os objetivos específicos são concernentes em desenhar uma conceituação mais exata da discricionariedade e procurar contribuir com aspectos clássicos concernentes ao tema.

Diante da vasta celeuma, da complexidade, da polivalência de definições, pode-se dizer que discricionariedade é uma noção confusa $a^{4} \mathrm{Ou}$

${ }^{4}$ A nomenclatura é encontrada em Chaïm Perelman e Lucie Olbrechts-Tyteca (2000, p. 149). Pouco mais adiante, na página 153 , em concepção bem adaptada ao tema aqui 
ao menos não é uma noção clara $^{5}$ para muitos. Discricionariedade e vinculação são comumente tomadas como termos excludentes ou antônimos, sem prejuízo da percepção de que um mesmo juízo (ato) pode contar simultaneamente com elementos discricionários e vinculados.

\section{O Equívoco Conceitual}

É muito comum se deparar com três afirmações acerca do juízo discricionário: 1) quando em decisão discricionária, o administrador está autorizado a decidir livremente sobre a opção que melhor atende ao interesse público; 2) o judiciário não pode apreciar o juízo discricionário; 3 ) o judiciário somente pode apreciar o juízo discricionário quando há abuso. A seguir as três afirmações são contestáveis. Calha lembrar a indagação de Bernard Schwartz (1991, p. 652), da Universidade de Nova York: "Indeed, what is administrative law if not the control of discretion?".

No final da década de 1940, Victor Nunes Leal, professor da Universidade Federal do Rio de Janeiro (UFRJ) e Ministro do Supremo Tribunal Federal (STF), após sublinhar que o poder discricionário é um terreno melindroso, "[...] onde a doutrina tem de utilizar instrumento de precisão para não vestir um santo com a roupa de outro [...]", afirmava que a delimitação do campo discricionário, “[...] a demarcação dessa zona livre é, em si mesma, uma questão jurídica, suscetível de apreciação jurisdicional" (LEAL, 1997, p. 278-294). Ou seja: há mais de 65 anos atrás, Nunes Leal, entre outros, já afastava a ideia de que o juízo discricionário traduz uma esfera estranha ao Direito, ajurídica ou, para utilizar termo ao gosto de tantos, um juízo político (equivalendo a dizer: sem pa-

versado, está escrito: “As noções confusas deixam aquele que as utiliza diante de dificuldades que, para serem resolvidas, requerem uma organização dos conceitos, uma decisão concernente à maneira de compreendê-las num caso dado. Essa decisão, uma vez admitida, terá o efeito de aclarar a noção em alguns de seus usos, nos quais ela poderá desempenhar o papel de noção técnica".

${ }^{5}$ Perelman e Olbrechts-Tyteca (2000, p. 153): "Uma noção parece suficiente clara enquanto não se vêem situações em que ela se prestaria a interpretações divergentes. Quando surge uma situação assim, a noção se obscurece [...]”. 
râmetros normativos). Ou seja: fica excluída a discricionariedade em sentido forte (DWORKIN, 1977).

Essa noção de discricionariedade revela um ganho àquela segundo a qual o juízo discricionário seria ilimitado pelo Direito, um juízo meramente subjetivo da autoridade, que deveria respeito exclusivamente à sua própria consciência. Por outros termos: se vai ao Direito, à legalidade, e nada se encontra. Como há um silêncio normativo pleno, o intérprete, agora não mais intérprete porque criador da norma, estabelece a decisão a partir das suas próprias convicções, inteiramente fora da juridicidade, incontido na sua subjetividade.

O que se costuma asseverar? Majoritariamente, que a decisão discricionária se materializa quando o intérprete pode escolher, entre duas ou mais, aquela que melhor atende ao interesse público (a expressão interesse público pode ser substituída, sem prejuízo, por direitos fundamentais ou por Constituição). O próprio Nunes Leal (1997, p. 283) escreveu:

[...] uma zona livre, na qual a administração, por si mesma, deve escolher 'entre as várias possibilidades de solução, aquela que melhor responda, no caso concreto, à intenção da lei', aí encontramos um campo de ação do poder discricionário. ${ }^{6}$

A demarcação desta zona livre, repita-se, está sujeita ao controle jurisdicional: portanto, não é livre, é limitada (tem fronteiras). Se cabe ao Judiciário definir as fronteiras dentro das quais o juízo discricionário se manifesta é porque a discricionariedade não é estranha à legalidade, somente será estranha em função da escolha que é livre (qualquer uma) entre as alternativas que são equivalentes (então, tanto faz). Por isto é melhor substituir a palavra melhor pela palavra equivalente (em função do empate que se dá).

Reiterando a asserção de Nunes Leal, posição muito difundida e que fez escola, Celso Antônio Bandeira de Mello afirma que há discricio-

\footnotetext{
${ }^{6}$ Não se discute aqui a menção à mens legis como baliza de eleição, anotando, porém, que o conceito de integridade do Direito, de Ronald Dworkin, é uma elaboração mais sofisticada e abrangente, em consonância com a figura do romance em cadeia.
} 
nariedade quando a legislação permite ao administrador a avaliação, por critérios próprios, "[...] quanto ao que lhe pareça ser o melhor meio de satisfazer o interesse público que a norma legal visa a realizar" (MELLO, 2007, p. 414).

Ou seja, é comum, aparentemente majoritária, a percepção de que o juízo discricionário se caracteriza por dois fatores: 1) decisão por critérios próprios, isto é, pessoais do agente público (administrador, legislador ou juiz), o que significa deliberação subjetiva, tendo em conta não existir parâmetro jurídico (normativo); 2) escolha, entre uma gama de possibilidades (duas ou mais), daquela medida que melhor traduza o interesse público, isto é, que mais esteja de acordo com o Direito, em conformidade com o sistema jurídico.

Impõe pontuar, diferentemente de Victor Nunes Leal e Bandeira de Mello, que, a rigor, quando em juízo discricionário o administrador não está autorizado a empregar critérios próprios, seus critérios pessoais, solipsistas ${ }^{7}$. Não. Os critérios são dados pelo Direito. Não importa o que o administrador individualmente, isolado na sua subjetividade, pensa. O que importa é o que o Direito prevê. O que se dá na discricionariedade é distinto, não se está na dependência do alvedrio personalista do administrador. $\mathrm{O}$ que ocorre é que, segundo os critérios normativos, há mais de uma resposta possível. Entre estas, as quais, saliente-se novamente, não são determinadas pelos critérios próprios do administrador (juiz, legislador, intérprete) e sim por critérios jurídicos, a escolha é livre. Entre estas, uma não é melhor do que a(s) outra(s). Se fosse, a melhor teria que ser adotada obrigatoriamente em detrimento das demais. Isto é: não haveria escolha. E, portanto, discricionariedade.

\section{Dando Nome à Coisa: juízo discricionário é juízo de empate}

A noção compartilhada de discricionariedade não autoriza o juiz a substituir a avaliação do administrador pela sua. Não porque isto traduziria a substituição de uma subjetividade solipsista pela outra (o que o

${ }^{7}$ Este o alvo da cruzada antidiscricionarista de Ronald Dworkin. No Brasil, a mesma cruzada é travada, entre outros, por Lenio Streck, âncora na Hermenêutica Filosófica. 
administrador achou melhor pelo que o juiz acha melhor), mas porque não existem parâmetros fático-normativos suficientes para se chegar à conclusão sobre um ato ser melhor do que outro; ou seja, não há baliza que faça concluir que uma medida satisfaz com mais propriedade ao interesse público do que a(s) outra(s). Logo, há discricionariedade quando existem duas ou mais decisões admitidas pelo Direito em igualdade, equivalência, isto é, não é possível saber qual é a melhor (OLIVEIRA, 2007, p. 127-173; OLIVEIRA, 2010, p. 354-369). As condutas discricionárias são igualmente razoáveis, nenhuma é melhor do que outra sob qualquer critério que importa juridicamente. Elas empatam. Dando nome à coisa, com Dworkin: juízo discricionário é juízo de empate.

Outra problemática, usualmente relegada ou não percebida com o devido cuidado, apesar de ser o núcleo da discricionariedade, que precisa ser enfrentada é a acepção da expressão igualmente razoáveis, a qual vem a identificar as escolhas. Até que ponto ou grandeza, sob quais critérios, é possível ou escorreito asseverar que duas ou mais decisões ou medidas são igualmente razoáveis? Essa igualdade razoável não precisa traduzir uma igualdade perfeita, milimétrica, mesmo porque, na maioria das vezes, não existe uma tal igualização, em tudo, inteiramente, ou não se logra mensurar com apuro a esse grau. Não é indispensável que um ato seja, fielmente, em todas as minúcias, idêntico ao outro para que se forme entre eles uma igualdade razoável. A própria palavra razoável está a indicar uma semelhança: as medidas devem ser análogas, sem que tenham que ser uniformes, coincidentes em cada pormenor. As distinções, todavia, não podem chegar ao estágio de apartar uma como a melhor. Admite-se uma simetria ou uma paridade relativa, uma similaridade, equivalência. Por outros termos: há discricionariedade quando existe dúvida razoável acerca de qual é o posicionamento correto, quando se tem a certeza de que existem dois ou mais posicionamentos igualmente acertados.

Como existe efetivamente opção, ou seja, há mais de uma medida possível, o que significa dizer que elas se igualam - uma igualdade que pode ser normativa, no sentido de que os bens são equivalentes, ou fática, no sentido de que não há como aferir qual ato é empiricamente o melhor (tenha-se em conta os três subprincípios do princípio da razoabilidade), qualquer decisão é possível entre aquelas acolhidas pelo Direito. Daí a 
razão pela qual o juiz não pode substituir a deliberação discricionária do administrador pela sua: não há critério para tal.

Ressalta-se: se é possível afirmar qual é a melhor medida para o interesse público, se uma é a melhor, não há empate, ela vence (é melhor do que a(s) outra(s)). E, desse modo, ela deve ser adotada, não é uma escolha, não há alternativa(s). Por outras palavras: não é juízo discricionário. Ao invés, o juízo é vinculado uma vez que a melhor (apenas uma, logicamente, é a melhor) medida é aquela que obrigatoriamente se impõe para ser adotada. O que se está, pois, a dizer, ao contrário, e. g., de Nunes Leal e de Bandeira de Mello, é que, se o administrador é capaz de divisar (por parâmetros jurídicos e não pessoais) qual a melhor decisão a ser tomada, esta é a única conduta cabível e, portanto, deve ser tomada. O juízo é vinculado e não discricionário. A melhor medida é a única medida. Ou, nos termos de Dworkin, a melhor medida é a única resposta certa. No juízo discricionário existe opção porque nenhuma, entre pelo menos duas ações equivalentes, é melhor do que a outra ou pelo menos não se consegue, com segurança, determinar qual é a melhor (limitação empírica da avaliação). Em termos jurídicos, que é o que importa, não se pode exigir qualquer atitude entre aquelas discricionárias. Por isto a zona de discricionariedade é zona livre: tanto faz a decisão que se tome em meio das que se situam nas suas fronteiras.

Sintetizando: juízo vinculado é sinônimo de única resposta certa (Dworkin); juízo discricionário é sinônimo de mais de uma resposta certa, ou seja, juízo de empate (Dworkin). Todo juízo discricionário é lícito porque se dá entre as respostas certas, a opção discricionária é uma resposta certa (não a única, não a melhor, pois não se sabe qual é a melhor; se é possível saber, a melhor é a única resposta certa e, portanto, o juízo é vinculado).

\section{A Pergunta Irrespondível e a Resposta}

Por outro lado, pergunta que se faz corriqueiramente é: pode o poder judiciário apreciar o ato discricionário? Bem observada, esta indagação carece de sentido. É uma pergunta que não pode ser respondida 
nos seus próprios termos. A resposta possível é prejudicar a interrogação. A resposta é: a pergunta está mal construída. Está mal formulada porque ela antecipa o resultado (na verdade, um dos resultados) da apreciação.

Afirmar que um juízo é discricionário é qualificar o juízo. Para qualificar um ato é necessário apreciá-lo. Por óbvio, sem tomar conhecimento do ato não é viável adjetivá-lo. Como o judiciário pode saber se a medida é discricionária sem examiná-la? Não pode. Como interditar a apreciação jurisdicional sob o argumento de que o ato é discricionário? Quem garante que se está diante de um juízo discricionário? Se a matéria foi levada ao judiciário é porque há dúvida sobre a qualidade da medida, alguém defende ser um ato discricionário (lícito) enquanto outro sustenta ser um ato arbitrário (ilícito). Como poderia o juiz se recusar a examinar a decisão sob o argumento prévio e não comprovado de que se trata de discricionariedade?

Analisar o caso é pressuposto para se saber o que há: vinculação, discricionariedade ou arbitrariedade (esta se manifesta quando não se adota a única resposta certa [vinculação] ou alguma das respostas certas [discricionariedade]). Examinar é, portanto e obviamente, condição de possibilidade. Para bem do uso do instrumento de precisão, aludido por Nunes Leal, é possível dizer que: em proveito da exatidão e da lógica, melhor é afirmar que aquilo que se investiga é um juízo de valor (a avaliação do administrador [mas também do legislador ou do juiz]), não um juízo discricionário. O juízo de valor pode ser legítimo ou ilegítimo. Se for legítimo, o juízo de valor é juízo discricionário. Se for ilegítimo, o juízo de valor é juízo arbitrário. Discricionariedade e arbitrariedade são adjetivos, propriedades dos juízos de valor. O juiz se debruça sobre o juízo de valor para declarar se é juízo arbitrário ou discricionário. Apenas desta maneira se afiguraria consequente assentar que o juiz não aprecia a discricionariedade (do mesmo modo que não aprecia a arbitrariedade), pois que ela é produto da intelecção do juízo de valor. De toda sorte, se o juízo de valor é, ao cabo, juízo discricionário, então o magistrado acabou por sindicar juízo discricionário, conquanto disto não soubesse até o término da aferição.

Algo é levado à apreciação do juiz. $\mathrm{O}$ que é este algo não se pode saber previamente. Não há bola de cristal ou um oráculo para dizer. Esse 
algo que é levado à aferição do judiciário é um juízo (decisão, ato, medida) levado a cabo pelo administrador. Se este juízo é discricionário ou arbitrário somente será possível determinar após a apreciação. E perceber isto é perceber o que há de mais simples. É o mínimo da coerência entre palavras e coisas. É o processo hermenêutico: não é possível denominar uma coisa (juízo) sem compreender esta coisa. Lembre-se que se houver dúvida em relação à qualidade do juízo, se legal ou ilegal, em nome da prudência que deve pautar o exercício jurisdicional, com esteio na presunção de validade dos atos administrativos, o juiz deve se abster de declarar a nulidade do ato. Nada de novo neste aspecto.

Com o objetivo de resolver o imbróglio narrado, a doutrina procurou uma fórmula a fim de sair do impasse concernente à legitimidade da investigação jurisdicional. O roteiro não foi suficiente para escapar do labirinto. Nas palavras de Seabra Fagundes (1951, p. 12), a sentença: “[...] a apreciação jurisdicional da competência discricionária só se dá quando dela abusa o funcionário administrativo, quando age exorbitando da esfera de ação livre que lhe deixa a lei". O Supremo Tribunal Federal vem de longa data repetindo esta assertiva. Em recente decisão, o STF reafirmou:

Na linha da orientação assentada pela jurisprudência desta Corte, a análise dos requisitos constitucionais necessários à adoção de medidas provisórias é, de regra, juízo político a cargo do Poder Executivo e do Congresso Nacional, no qual, salvo nas hipóteses de abuso, não deve se imiscuir o Poder Judiciário. (ARE n. 704520/SP. DJ, 02.12.2014. Relator Min. Gilmar Mendes)

Esse entendimento peca pelo mesmo motivo já exposto. Para ser mais exato, por duas razões. A primeira é que não é possível saber de antemão que há abuso no juízo discricionário para, então, se concluir pelo cabimento da sua apreciação. É precisamente o contrário: é indispensável (condição de possibilidade) examinar o juízo para que se possa afirmar que há abuso. Não há como antecipar a qualidade abusiva do juízo para aí concluir pela legitimidade da aferição. Reitere-se novamente: é preciso conhecer do juízo para se dizer alguma coisa sobre ele. A abusividade do juízo é sua adjetivação/qualificação, o que evidentemente apenas pode ser 
feito depois que dele se conheça. As formulações transcritas são contraditórias nos seus próprios termos.

De outro lado, em conformidade com o conceito firmado de discricionariedade, pode-se averbar que a expressão discricionariedade abusi$v a$ é também uma contradição, uma autonegação. Ora, se juízo discricionário é a eleição entre pelo menos duas medidas igualmente razoáveis, corretas, acolhidas pelo Direito, ou seja, se juízo discricionário é juízo lícito, então não é possível haver abuso. Se há abuso, o juízo é ilícito, inválido e, portanto, não pode ser discricionário. Ele é arbitrário. Trata-se do princípio da não contradição (Aristóteles), o qual, em proveito da identidade, enuncia que uma coisa não pode ser ela própria e o seu contrário ao mesmo tempo.

O que o juiz não pode fazer, mas isto é proclamar o óbvio, é invalidar um ato legal. Dito de outra maneira: o judiciário não pode afirmar a nulidade de um juízo discricionário. Pela simples razão de que não existe nulidade a ser declarada: o juízo é lícito. O que o juiz deve fazer, mas isto também é averbar uma obviedade, é assentar o vício do ato arbitrário, pronunciar a sua ilegalidade. Para tanto, ressalte-se pela última vez, ele não pode se recusar a apreciar o ato sob o argumento de que se trata de ato discricionário ou só se permitir ao exame quando houver abuso da discricionariedade: ninguém pode saber se o juízo é discricionário ou arbitrário antes de apreciá-lo.

Calha registrar que a arbitrariedade se configura por desrespeitar tanto a vinculação (sentido forte) quanto a discricionariedade. Duas as situações: 1) o ato (comissivo ou omissivo) é arbitrário, equivocado, porque não é o único comportamento correto - por exemplo: embora a norma determine, exclusivamente, a prática de $A$, a única resposta certa, o sujeito pratica $B$ ou não pratica $A$ (segue inerte); 2) a conduta (ação ou omissão) não se encontra entre qualquer das admitidas ou exigidas pelo Direito, não está no rol das posturas pertinentes - por exemplo: a Constituição enseja três atitudes, $A, B$ ou $C$, porém o sujeito executa $D$ ou não realiza nem $A$, nem $B$ e nem $C$ (segue inerte).

O máximo que se pode cogitar é que alguns juízos estão inseridos em âmbitos onde há uma dificuldade maior para precisar qual a melhor decisão ou mesmo para delimitar os contornos do campo discricionário. 
Não se pode perder de vista que a separação de poderes reserva uma esfera de liberdade para cada poder. Por exemplo, pode ser que centrar as apostas no Mercosul não seja a melhor medida para o Brasil, mas como existem circunstâncias que o judiciário não conhece - a valorização das chamadas capacidades institucionais -, como existe dúvida a respeito, não seria cabível, salvo uma hipótese extrema, anular judicialmente a decisão de integrar o bloco econômico ou de recrudescer os vínculos. Nem tudo se pode solucionar pela via judicial: muita coisa não pode. Tomemos outra ilustração: indicação de ministro para o STF. Nem todos os brasileiros natos, inclusive entre os bacharéis em Direito, são elegíveis para a função. Nem todos possuem notório saber jurídico e reputação ilibada. Conceitos jurídicos indeterminados, como se sabe, não geram necessariamente discricionariedade. Nada obstante, como há uma vagueza na análise destas qualificações, seria exótica, embora não impossível, uma decisão judicial que viesse a declarar a invalidade de uma nomeação. O exotismo estaria na indicação e aprovação pelo senado de alguém que flagrantemente não reúne as condições para integrar o STF.

Supõe-se que a chefia do executivo promova uma indicação razoável. Pode até ser que o indicado não seja o melhor (esta seria a resposta certa), porém, na falta de elementos para se concluir, com segurança, isto é, induvidosamente, quem é o melhor para assumir uma cadeira no tribunal, a escolha do executivo, aprovada pelos senadores, uma vez localizada no campo da razoabilidade, deve ser mantida. Qual seria o equívoco aqui? O equívoco seria o judiciário, instado a se manifestar acerca da validade de uma indicação, responder de pronto que o juízo é discricionário e que, desta forma, não lhe compete sindicar. Pode não ser. Pode ser que a indicação tenha se dado sobre uma pessoa sem reputação ilibada ou sem notório saber jurídico. E isto seja patente. Não é o que se presume em um regime republicano, onde os poderes estejam funcionando razoavelmente bem. Mas, excepcionalmente, pode ocorrer (nomeação arbitrária). O que o judiciário deve fazer? Examinar, com a contenção devida, a decisão. Nenhuma deliberação é, por princípio, abstratamente, em tese, preliminarmente, discricionária.

Mais uma vez: não se sustenta que o juiz está autorizado a substituir a avaliação do administrador pela sua, trocando subjetivismo por subjeti- 
vismo. Ou existe um critério para se afirmar que uma medida é melhor do que outra, o que significa que não há empate e, portanto, a melhor medida deve ser adotada, quando então não há discricionariedade e sim vinculação, ou não há critério, existem medidas iguais/equivalentes e, nesta hipótese, o juiz não pode invalidar a decisão administrativa precisamente porque não existem parâmetros de legalidade para tal (embora existam balizas normativas que circunscrevem o domínio no qual a eleição ocorre). Na hipótese da indicação para o STF, mesmo que o judiciário viesse a anular uma indicação (deveria ser ainda mais comedido se a indicação já conta com a aprovação do Senado), a anulação, situação excepcionalíssima, se daria muito provavelmente pelo fato da pessoa não ser indicável/aprovável, ou seja, não estar no universo dos indicáveis/aprováveis e não por ela não ser a melhor indicação. Por outros termos: a indicação não foi uma resposta certa (entre outras, portanto), a indicação/aprovação não foi discricionária. Daí que, conquanto eventualmente viesse a anular uma indicação/aprovação, o judiciário não poderia ele próprio estabelecer o novo ministro, o que seria a afirmação da única resposta certa. Isto por dois motivos: 1) pela falta de parâmetros confiáveis de aferição bastantes a gerar certeza de que alguém é, seguramente, a melhor indicação para o tribunal; 2) porque, ainda que o tribunal estivesse convicto de que alguém é o melhor para o cargo, a decisão não é da sua atribuição, não lhe cabe.

Por último, algumas notas importantes. Por tudo o que se expôs, o judiciário está legitimado, pois é seu dever, a adentrar no mérito administrativo, a analisar o juízo de conveniência e oportunidade realizado pelo administrador. Afirmar que o mérito é insindicável (Seabra Fagundes, Diogo de Figueiredo Moreira Neto) é contribuir para o imbróglio que se vem a referir. Não favorece, ademais, separar mérito de juízo de conveniência e oportunidade (Nunes Leal). O juízo de conveniência e oportunidade é o juízo de mérito (sobre ser a medida conveniente e oportuna). Por outro lado, não é procedente seguir afirmando que na análise do mérito o judiciário não faz exame de legalidade. Tal seria distinguir juízo discricionário de juízo de legalidade (Eros Grau). Repita-se: o juízo discricionário não é um juízo alegal, ajurídico, fora ou estranho ao Direito. Claro, esta é a legalidade pós-positivista, a legalidade material e não meramente for- 
mal, a legalidade dos princípios, a legalidade constitucional ou, caso se prefira, a simbiose entre legalidade e legitimidade.

\section{Conclusão}

É possível abordar a temática da discricionariedade por ângulos distintos, manejando matrizes teóricas diferentes. Como dito, o foco deste texto foi o Direito Administrativo. Em que pese ser questão central da matéria - na verdade, do Direito como um todo -, há mesmo uma grande confusão terminológica, conceitual, linguística. Parece, por vezes, que pouco se avança: que se anda em círculos ou mesmo se regride. Ou que se está preso em um labirinto de contradições e aporias.

Veja-se o exemplo do tombamento. Repita-se a pergunta já feita várias vezes: o tombamento é um ato discricionário ou vinculado? Não é possível afirmar em tese, em abstrato. Depende da hipótese concreta. É possível anular judicialmente um tombamento? Sim. Se o tombamento for arbitrário, feito com desvio de finalidade, a partir de uma má avaliação das qualidades históricas/culturais do bem, o tombamento deve ser invalidado. E a jurisprudência é firme na acolhida desta possibilidade. Contudo, para outra indagação a resposta é vacilante: é possível reivindicar um tombamento? Sim também: inclusive pela via judicial. Ora: ou o bem tem as propriedades que justificam a proteção estatal e deve, pelo menos com forte presunção, ser preservado ou não tem e, por conseguinte, não deve ser tombado. Se há dúvida, em função da presunção que milita em favor do Estado, o tombamento deve ser mantido ou não deve ser determinado judicialmente.

Devido à objetividade presente na avaliação (índole técnica, pericial) a respeito das características do bem, apenas muito excepcionalmente vai haver discricionariedade na qualificação do objeto. A discricionariedade pode se manifestar, mas ainda assim será rara, frente aos efeitos que o tombamento pode ter em concorrência com outros interesses públicos. Por exemplo: a despesa que será assumida pelo Poder Público para a conservação do bem diante da carência de recursos do proprietário ou o impacto no planejamento urbano em meio a outras demandas (demolição para constru- 
ção de uma praça ou modernização total do bem). O interesse no tombamento pode ser equivalente a outro interesse público: se isto acontecer, há empate, juízo discricionário. Porém, é difícil ou raro que tal aconteça.

Reitere-se que somente é possível determinar se há vinculação, discricionariedade ou arbitrariedade diante de uma hipótese concreta. Por mais inusitado que possa parecer, não é viável olhar apenas para o texto legal e asseverar que existe vinculação ou discricionariedade. Por isto a antiga celeuma doutrinária, travada em abstrato e genericamente, com base na letra do direito positivo, sobre se a decisão do tombamento é vinculada ou discricionária não faz sentido, não tem lógica.

Os chamados conceitos indeterminados se determinam perante o caso concreto (são conceitos determináveis) ${ }^{8}$. Por vezes, esta determinação leva à vinculação; por vezes, leva à discricionariedade. O princípio da razoabilidade, como flagrante, encaminha decisivamente, essencialmente, a tarefa de densificação dos conceitos elásticos, reduzindo ou terminando com a indeterminação. A própria nomenclatura conceitos elásticos é bem esclarecedora, porquanto anuncia que tais conceitos podem englobar dúvida razoável, duas ou mais interpretações, duas ou mais ações ou omissões, porém esta elasticidade vai somente até um ponto, não pode

${ }^{8}$ Calha mencionar uma polêmica acerca da sede da imprecisão: se está nos vocábulos ou nos conceitos. Eros Grau sustenta que a indeterminação é das expressões, pois que a afirmação de que os conceitos são indeterminados seria uma contradição de termos, já que todo conceito ou definição pressupõe determinação. Já Celso Antônio Bandeira de Mello perfilha a compreensão de que a fluidez é uma característica do próprio conceito e não do vocabulário. Conferir em Grau (1995, p. 309 e ss.), Mello (2000, e.g., p. 21). Concorda-se com Bandeira de Mello: a indeterminação está, realmente, nos conceitos (concepções) em si, não nas expressões que traduzem as ideias. A fluidez está na ideia, no pensamento, não na palavra que serve de instrumento. O que importa é o conceito que se dá ao vocábulo, haja vista que o vocábulo não possui qualquer definição por conta própria, isoladamente, mas sim por meio de uma convenção. Cumpre ressaltar que esta dação de significado ao significante é decorrência de um juízo material. O problema é de conteúdo, não de forma. Não é o vernáculo que padece, por si mesmo, de imprecisão, mas sim as atribuições de sentido. Se fosse o contrário, a solução seria simples: bastaria substituir uma palavra ou uma redação indeterminada por uma palavra ou redação determinada e estaria tudo resolvido. 
se romper; são elásticos, não inconformados. É dizer: é sempre possível controlar, aferir, juízos tomados com base em conceitos indeterminados. ${ }^{9}$

O conceito fluido acalenta uma densidade mínima, a partir da qual sua concretização se desenvolve. O conteúdo mínimo traduz o acordo mínimo que se tem acerca da materialidade do conceito. Existe, pois, um mínimo determinado, o qual conforma o início do processo de densificação. Conceito indeterminado não significa conceito descompromissado, não é sinônimo de conceito vazio. A densidade mínima espelha a determinação prima facie de tais conceitos e contribui a explicar a conformação da obra metodológica de densificação.

O debate vai continuar e ele seria facilitado se fosse estabelecido um acordo mais largo e sólido sobre palavras e coisas.

\section{Referências}

ALEXY, Robert. Teoría de los derechos fundamentales. Tradução por Ernesto Garzón Vades. Madrid: Centro de Estudios Constitucionales, 1993. CADEMARTORI, Luiz Henrique Urquhart; OLIVEIRA, Vitória Cristina. Constitucionalização do Direito Administrativo e a sindicabilidade do ato discricionário. Revista de Estudos Institucionais, Rio de Janeiro: UFRJ, v. 2, 1, p. 168-191, 2016.

DWORKIN, Ronald. Taking rights seriously. Cambridge, Massachusetts: Harvard University Press, 1977.

ENTERRÍA, Eduardo García de. Democracia, jueces y control de la administración. 3. ed. ampl. Madrid: Civitas, 1997.

FAGUNDES, Miguel Seabra. Conceito de mérito no Direito Administrativo. Revista de Direito Administrativo, [S.l], v. 23, p. 1-16, jan.-mar., 1951.

GARCÍA DE ENTERRÍA, Eduardo. Democracia, jueces y control de la administración. 3. ed. ampl. Madrid: Civitas, 1997.

${ }_{9}^{9}$ Nesse sentido, e.g., García de Enterría (1997, p. 141 e 142). 
GRAU, Eros Roberto. Crítica da discricionariedade e restauração da legalidade. In: ROCHA, Cármem Lúcia Antunes Rocha. (Coord.).

Perspectivas do Direito Público: estudos em homenagem a Miguel

Seabra Fagundes. Belo Horizonte: Del Rey, 1995. p. 307-335.

LEAL, Victor Nunes. Poder discricionário e ação arbitrária da Administração. In: LEAL, Victor Nunes. (Org.). Problemas de Direito Público e outros problemas. Brasília: Ministério da Justiça, 1997. p. 278-294.

MELLO, Celso Antônio Bandeira de. Curso de Direito Administrativo. 23. ed. Rev. Atual. São Paulo: Malheiros, 2007.

. Discricionariedade e controle jurisdicional. 2. ed. São Paulo:

Malheiros, 2000.

OLIVEIRA, Fábio Corrêa Souza de. Morte e vida da Constituição Dirigente. Rio de Janeiro: Lumen Juris, 2010.

. Por uma teoria dos princípios: o princípio constitucional da razoabilidade. 2. ed. Rev. Atual. Rio de Janeiro: Lumen Juris, 2007.

PERELMAN, Chaïm; OLBRECHTS-TYTECA, Lucie. Tratado da argumentação: a nova retórica. Tradução por Maria Ermantina Galvão. São Paulo: Martins Fontes, 2000.

SCHWARTZ, Bernard. Administrative Law. 3. ed., Boston: Little, Brown, 1991.

STRECK, Lenio Luiz. Verdade e consenso. 4. ed. São Paulo: Saraiva, 2011.

Fábio Corrêa Souza de Oliveira professor de Direito Administrativo da Faculdade de Direito da Universidade Federal do Rio de Janeiro (UFRJ). Professor do PPGD/UNESA e Diretor do PPGD/UNIFG (Centro Universitário GuanambiBA). Mestre e Doutor em Direito pela UERJ, Pesquisador Visitante e Pós Lato Sensu na Faculdade de Direito de Coimbra (2004-CAPES). Pós-Doutorado em Direito na UFSC (2007-2009-CNPQ).

E-mail: fabiocsdeoliveira@gmail.com

Endereço profissional: Rua Moncorvo Filho, n. 8, Centro, Rio de Janeiro - RJ, CEP. 20.211-340. 